\title{
The Validity of Hybridity in Derek Walcott's A Branch of the Blue Nile
}

\author{
Zohreh Ramin \\ Department of English, University of Tehran, Tehran, Iran \\ Monireh Arvin \\ Department of English, Alborz Campus, University of Tehran, Alborz, Iran
}

\begin{abstract}
With A Branch of the Blue Nile (1983) Derek Walcott makes a strong statement for the validity of a hybrid West Indian culture. He portrays the relation between European, specifically English, as well as American and African culture as one that should not be marked by a hierarchy, placing the central culture and languages at the top and African or mixed cultures/languages at the bottom. Walcott's strategy here is to show that the so-called standards, Shakespeare's 'classical' plays and their language are already of a hybrid nature, and any attempt to characterise them as homogenous entities and preserve them as such may ultimately result in their inertness. What threatens a civilisation or culture, according to Walcott, is not some form of hybridity, but rather the closing off or preservation of artistic forms from other foreign influences because it makes these artistic forms incapable of interacting with the surrounding cultural environment. The authors of this paper while appreciating all the orchestrated bonus of the existing relevant criticisms on hybridity towards Walcott's A Branch of the Blue Nile intend to examine the use of Bakhtinian notions with regard to language exemplifying Bakhtin's view of linguistic interanimation and his insights into the "polyglotic" and "heteroglotic" nature of the play. The purpose of this article is to provide the readers with a quest for the formation of Caribbean identity, beyond dualism, through the vernacular. Walcott portrays the vernacular as being capable of voicing the ideas necessary to define one's identity.
\end{abstract}

Index Terms - Caribbean identities, Creolisation, hybridity, Trinidad, vernacular

\section{INTRODUCTION}

A Branch of the Blue Nile premiered in Barbados on November 25, 1983. The play mirrors many of Walcott's ongoing concerns, for example the relationship between classical and folk art and the artist's need to leave home in order to advance their talent. It seems to make more sense to follow Bruce King's insight that "It might be better to regard the characters as composites of people Walcott knew" (Derek Walcott, 1981, p. 334). The play is set in Trinidad, and its opening scene depicts a rehearsal of Shakespeare's Antony and Cleopatra.

Through the act of staging his creolised Antony and Cleopatra, Walcott shows that even if a cultural form, an artistic expression, was once shaped through its place of origin, it is legitimate to transport it to another culture and let it be influenced by this culture (in this case through its language) as it is the only way through which it will stay alive and have meaning. In A Branch of the Blue Nile, Walcott portrays the vernacular as being "capable of voicing the ideas necessary to define one's identity." He also shows us in this play "the value that should be attached to the use of the vernacular on the West Indian stage, its importance for a definition of the West Indian cultural identity" (Sinnewe, 2001, pp. 122-123).

The three cultural strands which Walcott explores through A Branch of the Blue Nile, the American, the European and the West Indian culture, according to Dirk Sinnewe, are initially represented through: Gavin, the Trinidadian actor who sought success in the United States (who speaks with an American accent): then there is Harvey St. Just, who went to work in London and consequently has a British accent (Walcott's stage direction insists he is white. He is the only actor whose skin colour in the dramatis personae seems of importance); and finally there is Chris, who has always worked in Trinidad and speaks with a Trinidadian accent (2001, p. 90).

Bruce King in his essay, "The Collected Poems and Three Plays of Derek Walcott" (1987), argues that A Branch of the Blue Nile (1985) tests the applicability of European art and ambitions to West Indian society. As a fledgling West Indian theatre company rehearses Antony and Cleopatra, tension develops between the white director returned from England, a black West Indian actor who studied in New York, and Christopher, a married Trinidadian who writes plays in dialect and sleeps with Sheila, the Cleopatra. The rehearsal of the play is applicable to West Indian society: "If there's disorder here, in this little world, no trust, no centre, no authority, then lunacy is correct, we're wasting time. What is wrong in here is what's wrong with this country. Our country. And if, outside, there's mismanagement and madness, we must not go mad" (Walcott, Branch, 1986, p. 223).

Although the critical output on Walcott's play, A Branch of the Blue Nile, is on a small scale in quantitative terms, it is nonetheless of a volume which precludes exhaustive treatment in this paper. Instead criteria have to be found which 
will limit the number of works discussed, but which still allow for an informative overview of the field. The researchers have therefore considered the works of those scholars who deal with Derek Walcott's dramatic work in greater detail. The first and to date most influential is Robert Hamner. His Derek Walcott (1981) predates Bruce King's Derek Walcott and West Indian Drama (1993) as well as Judy Stone's "Classical Theatre" in Theatre: Studies in West Indian Literature (1994) by more than a decade. The latest monograph which focuses in greater depth on Walcott's dramas is John Thieme's Derek Walcott (1999). Most of these critical writings on Walcott's A Branch of the Blue Nile are essays in scholarly journals, published mainly in North-America and England. Their approaches towards Walcott's play are some prevalent examples of currently dominant critical schools, which are: post-modernism, post-colonialism and feminism.

Bruce King's Derek Walcott and West Indian Drama, is to date the only monograph written exclusively on the subject of Walcott's play, but nevertheless there is as yet no single authoritative study which can be said to have influenced the writings of others. Although Derek Walcott and West Indian Drama is admirable in that it gives a detailed historical account on Walcott's Trinidad Theatre Workshop, including cast lists and numerous bits and pieces of reviews, it at times loses sight of the issues of literary criticism. While King's stated aim of integrating the study of practical theatre "with theatre history and literary criticism" (King, Derek, 1981, p. vii) is achieved, the overall focus of King's work is on a detailed account of theatre history rather than on literary criticism.

Robert Hamner's Derek Walcott which since its publication has acquired influential status within the field of the researchers' study begins with a description of the historical background out of which West Indian literature per se developed. He mentions three aspects leading to the particularities in terms of cultural and racial mixture of the West Indian situation; the geopolitical separation. Hamner's emphasis is on synthesis, on assimilation, the creation of a new (cultural) identity. He sees Walcott's play as an example of folk stories and the traditional themes of European experience. Hamner's necessarily incomplete account identifies a later phase which includes A Branch of the Blue Nile (1983). In this case Hamner maps out parallels between the play and Walcott's own experiences with the Trinidad Theatre Workshop. He sees the play as again crowning a phase in Wolcott's career as a playwright and as being the most self-reflexive of all of his plays.

Like Hamner, John Thieme in his Derek Walcott (1999) concentrates on the fact that Walcott is of a mixed racial heritage and that he grew up within an English-speaking middle-class Methodist environment on Castries on the island of St. Lucia, which still has an overwhelmingly Catholic and francophone population. Thieme sees "the dismantling of Manichean binarisms as the key issue of Walcott's art", which allowed for a "cross-cultural practice, long before hybridisation theory became internationally fashionable in the 1980s through the work of post-colonial writers and theorists such as Salman Rushdie and Homi Bhabha” (1999, p. 9). The words hybrid and hybridity permeate Thieme's assessment of Walcott's dramatic production. In another, rather generalising step Thieme then talks about the Creolisation, that is the hybridisation, of all cultures. Thieme shows awareness of the generalising potential of "Creolisation", however, and indicates the questionable theoretical value of the term hybridity when taken on its own, "without addressing the socio-political factors which determine the lives of the socially immobile wretched of the earth who have little or no sense of the positive dynamics of living between cultures" (Thieme, 1999, p. 126).

In her Theatre: Studies in West Indian Literature (1994) Judy J. Stone gives a historical overview of theatre located in and emanating from the region. She structures her book around the proposition that there are five types of theatre in the West Indies: the theatre of realism, the theatre of the people, total theatre, theatre of ritual, and classical theatre. Under this latter heading she subsumes A Branch of the Blue Nile as she claims that Walcott's theatre "draws much of its strength from ancient values" (1994, p. 92). Stone sets Walcott's dramatic work against the background of realistic and popular drama. According to Stone, the basic themes of Walcott's dramatic work are "universal", but she identifies the dichotomy between two cultures, the classical and the Creole, as the most frequently recurring theme, resulting from the colonial legacy of the West Indies, (Stone, 1994, p. 92).

Stone claims that contemporary critics' dislike of the classic form of the play missed the point that the play's greatness hinged precisely on the fact of not drawing on realistic material. At this point she draws a parallel with Walcott's play A Branch of the Blue Nile with its exploration of the dilemma of the West Indian artist and the conflict between classical and Creole linguistic and theatrical forms (1994, P.101). She claims that with A Branch of the Blue Nile the playwright investigates whether or not the classical form has any place in the Caribbean cultural environment. Here she even goes so far as to interpret such a question as an examination of the "validity" of Walcott's own role in the West Indies (Stone, 1994, p. 136).

Even in the light of Stone's own discussion of Walcott's dramatic work, her exclusive focus on the classical-Creole dichotomy can be seen at times as an overtly reductive reading, although this shortcoming is balanced by the fact that Stone's "Classical Theatre" provides us with more detailed accounts of Walcott's play. To complement her approach and the other aforementioned approaches towards Walcott's play A Branch of the Blue Nile, the researchers have decided to read the play once more under the lights of Bakhtinian perspective of linguistic interanimation to discern Walcott's textual shifts and their dramatic implications: the distinction between his reasonably harmless actors' jokes and the deeper truth and fate of their lives. One might be tempted to read Walcott's play as simply a "heteroglotic parody" of Shakespeare through which the serious implications of Walcott's drama finally catch up with and triumph over the play's comic elements. A Branch of the Blue Nile wonderfully fulfills many of Bakhtin's concepts of "parodic heteroglossia," a multitude of linguistic shifts that demonstrate a seriocomic imagination that mixes low and high forms. 
Here the use of Bakhtinian notions with regard to language helps us to avoid ideological simplifications. For Bakhtin, hybridity is a phenomenon of language formation, but also of the concrete and social act of language use.

In the following the researchers will briefly present an exemplary approach which examines Walcott's play more or less explicitly in terms of present literary theory to deepen our understanding of the orchestrating function of Walcott's philosophical reflections on The Trinidadian Theatre and on Walcutt's notion of language use, that is, specifically the use of non-Standard language, to divulge its relation to the formation of West Indian (cultural) identities.

\section{DISCUSSION}

\section{A. Trinidadian Heteroglossia: A Bakhtinian View of Derek Walcott's A Branch of the Blue Nile}

Multiple voices form the central fabric of drama. Variable speech patterns and intonations, differing uses of standard, slang, and dialectal language create, from a purely textual point of view, the chief differentiating features of dramatic dialogue. Bakhtinian theory, especially evident in The Dialogic Imagination, contains a vast number of insights into the "polyglotic" and "heteroglotic" nature of the modern novel. Although Bakhtin reserves the majority of his notions for criticism of the novel, many of them would apply equally, if not more pointedly, to drama.

Occasionally Bakhtin makes excellent use of examples from the history of drama; for example, he cites the "heteroglotic" nature of the commedia dell'arte: "In the commedia dell'arte Italian dialects were knit together with the specific types and masks of the comedy. In this respect one might even call the commedia dell'arte a comedy of dialects. It was an intentional dialectological hybrid" (Bakhtin, The Dialogic Imagination, 1981, p. 82). This example emerges out of a discussion in which he announces his central critical insight: "In the process of literary creation, languages interanimate each other and objectify precisely that side of one's own (and of the other's) language that pertains to its world view [Bakhtin's italics], its inner form, the axiologically accentuated system inherent in it" (Bakhtin, The Dialogic Imagination, 1981, p. 62).

Walcott's A Branch of the Blue Nile wonderfully exemplifies Bakhtin's notion of "heteroglossia." In the play Walcott draws upon his rich African, patois, French, English, and classical Latin linguistic legacy, his St. Lucian and Trinidadian heritage, and his long experience in the United States, to bring his mastery of heteroglotic language to a peak. He continues the sort of "black/white, coloniser/colonised cultural reversals" that he played with in his earlier drama, Pantomime, by means of his "Crusoe/Friday role shifts." He also compounds his fascination with the Antony and Cleopatra legend, which configured several of his major poems, such as "Egypt, Tobago." Intertextual and intercultural references, woven through much of Walcott's poetry and drama, multiply exponentially in A Branch of the Blue Nile (Hamner, 1997, p. 388).

From the beginning of the play, "and arching over its entirety, looms the voice of Shakespeare" (Hamner, 1997, p. 388). Walcott's characters are the actors and the director of a Trinidadian production of Antony and Cleopatra. As they are knitting together their Shakespearean lines, they themselves are interwoven into a complex cloth of "real life" interrelationships, many of them mirroring the characterisations and meanings inherent in Shakespeare's drama. The play opens as Sheila, playing Cleopatra, is enacting the queen's final scene:

SHEILA: Give me my robe, put on my crown, I have

Immortal longings in me: now no more,

The juice of Egypt's grape shall moist this lip. (Walcott, Branch, 1986, p. 213)

Harvey, the aging English "queen" director (there are strong hints he is a homosexual), immediately rejoins with a bit of directorial advice regarding her performance: "What's all this sexual hesitation, Sheila? You know how sensual his corpse is to her?"

Walcott's stage, then, from the outset reverberates with reflexive consciousness of itself. From this point forwards Walcott "delights in masterful interanimation of Shakespeare's text: his actor's reproduction of Shakespeare's play, their own personal responses to the bard", their playing with his text, and their "real life," interpersonal texts that form the basis of Walcott's overall dramatic action. Two more series of these combinations compound the intertextuality when the characters read parts of Chris's (one of the actors) texts, three "plays" he has written: one a simple-minded pastoral farce, another a symbolic representation of these same actors" "real life" relationships, and the third a wordfor-word tape recorder transcription of their conversational and rehearsed lines onstage preliminary to performance. "Walcott herein clearly displays a postmodern sensibility: the text within the text within the text." However, he shies away from any "avant-garde" break with the "traditional boundary of the proscenium arch, as achieved by such dramatic figures as Pirandello's eponymous Six Characters in Search of an Author, who interact directly with the audience." Walcott's play remains "onstage, 'yet it greatly enlarges the number of purely heteroglotic, interanimating dramatic languages" commonly found in contemporary plays (Hamner, 1997, p. 389).

Soon after the play's outset, Harvey directs Sheila/Cleopatra to "play what you feel about Chris, not Antony" (Walcott, Branch, 1986, p. 213). Harvey's suggestion emerges from his training in method acting; in addition, he is playing on what he knows is going on behind the scenes: Sheila's affair with Chris. It is at this early juncture that we can already assess the deeply cutting conflicts that brew at the interfaces of the play's various languages. Harvey's directorial remark rapidly interanimates Sheila's played version of Shakespeare's Cleopatra and identifies the play as a hybrid seriocomedy; the dialogue is too violent, too cutting, for it to be read as light, parodic comedy. Harvey's suggestion strays towards improper use of his directorial power, and Sheila is clearly in the right to tell him, "Just leave 
my private life out of this, please" (Walcott, Branch, 1986, p. 213). Sheila may well feel as Shakespeare's colonial queen felt when she expressed, at the end of her tragedy, that she deeply resented the idea that her play (that is, the story of her life) would be comically performed in Rome, the imperial capital, where "the quick comedians / Extemporally will stage us" (Shakespeare, Antony and Cleopatra, 1969, Act V, Scene 2, Lines 216-217).

Unfortunately, as Walcott repeatedly reveals, there does not appear to be any way for these characters to separate their private lives from their professional acting roles. The two realms are inextricably mixed, and their multiple interactions form the central action and meaning of the play. Even on the most minute linguistic level, when Walcott's actors unavoidably interject their Trinidadian accents into Shakespeare's text-when Chris, for example, blurts "Your Lord? No. He gone out" (Walcott, Branch, 1986, p. 214)—Trinidadian and Shakespearean languages are comically interwoven. This commingling of the performer's natural language with the language of the staged text adopts even further import, when we perceive it in extended cultural and political terms: "the post-colonial, former slave society struggling to re-enact the masterpieces of the coloniser's culture, and the post-colonials chastising each other for not getting the masterpiece right" (Hamner, 1997, p. 390).

The Trinidadian actors strike back, however, with their parody of Harvey's Americanisms, in particular his perpetual use of the term 'whatever'. Gavin's satiric jibes are pointed at the director: "Would one of you care to ask Mr. Strasberg here what he means by 'whatever?"; and later, "I'm going to be acting whatever, Chris, you hear. You ready?" (Walcott, Branch, 1986, p. 215) Gavin, the craftiest parodist of the troupe, parries with Harvey when he assumes the role of the victimised plantation slave: 'You'se a hard taskmaster, Mistuh Harvey sur, you'se going make this po' nigger tote your arse across the desert, you'se pitiless as that burning sun, Mistuh Harvey. Why? Why'?" (Walcott, Branch, 1986, p. 221) Harvey, with the arch finesse of his years on the North American stage, and his practised position as a white among blacks, plays right into Gavin's game without missing a stroke: "Whah? Whah? I'se pitiless 'caue I can't trist you house niggers, 'cause I leave you to polish the silver back in the pantry and you fucked the help, you been inter-fering. And you knows mah punishment for house niggers, boy?' Gavin foolishly continues the game and gets hit harder than he expected. He asks Harvey, in his role as plantation overseer, “[Whining, pulling at Harvey's trousers] No, Mistuh Harvey, what is it?" But Harvey suddenly shifts context on Gavin with his masterful, cynical, and politically loaded rejoinder: "They gits to be on television. They gits to be third detectives in a police series. They gits to do serious theatre in a side alley, in Noo Yawk. So git up. Git up!” (Walcott, Branch, 1986, p. 221)

Overall, this parodic technique exemplifies Bakhtin's view of linguistic interanimation, present in Roman times in writers such as Lucian and in medieval parodia sacra. In such parodies writers would take a serious text-Homer, for example, or the Bible - and ridicule it by inserting alternate, comical words, lines, and situations. "The seriocomic form, thus born, was responsible, according to Bakhtin, for the rise of the novel and the demise of traditional serious forms such as the epic." In Walcott's play the serious text is supplied by Shakespeare's Antony and Cleopatra, yet often the parodying form shifts to another language, such as the speech of the southern U.S. plantation black cited above. With a Bakhtinian perspective, we can more easily discern Walcott's textual shifts and their dramatic implications: the distinction between his reasonably harmless actor's jokes and the deeper truth and fate of their lives. "The predictable, ritualistic 'agon' of the stage rehearsal frequently disintegrates into a variety of sobering, 'real life' conflicts that plague the various members of the troupe" (Hamner, 1997, pp. 390-391).

Sheila, playing Cleopatra, has the dimensions of a star, but her aspirations to "make it big in the States" are jeopardised by her provincial location and her cumbersome affair with the married actor Chris (a situation that echoes the historical tragedy of Antony, Cleopatra, and Antony's wives Fulvia and Octavia). One might be tempted to read Walcott's play as simply a "heteroglotic" parody of Shakespeare, if A Branch of the Blue Nile did not have its own tragic dimensions. "The separate intrusions of real life into the rehearsal text become more and more numerous and disruptive until both their performance of Shakespeare and the actors' psyches unravel completely" (Hamner, 1997, p. 391).

Sheila bows out, as it were, and bequeaths her throne to Marilyn, another actress who is less talented and less idealistic but more ambitious. Sheila undergoes a religious conversion, quits the stage, and hands the part of Cleopatra over to Marilyn. She abandons the theatrical tent for God's temple, and Walcott litters his text with frequent interanimated comments between the two worlds, the secular and the divine. Still, dramatic language in general, for Walcott, clearly remains the centering force of what might be seen as an example of Bakhtin's notions of the "centrifugal" and "centripetal" tendencies of language. With only a couple of short scenes between Sheila and her newfound mentor, Brother John, Walcott provide just enough dialogue to parody the superficiality and hypocrisy of fundamentalist religious sects. In a brilliantly crafted "benediction" at her temple, a speech which reeks of double meaning-she hears "the voice of William Blake in the fields" (Walcott, Branch, 1986, p. 265)— "Sheila bares her naturally talented poetic and theatrical soul to the massed congregation, which is clearly impressed by the "style" and passion of her eulogy, although not its moral content" (Hamner, 1997, p. 391).

We are soon back “onstage," however, with Marilyn's performance as Cleopatra and with Harvey's new "dialectal" version of Shakespeare's text. The director decides to interweave the local, dialectal intonations of one of Chris's plays with Antony and Cleopatra. "The result is exceedingly amusing and certainly would rival the heteroglotic interanimation and wit of the finest commedia dell'arte productions" (Hamner, 1997, p. 391). Marilyn plays her 
traditional Shakespearean text straight, but Gavin, playing Shakespeare's clown, gives a hilarious Trinidadian, dialectal takeoff on the great play by the imperial bard:

MARILYN/CLEOPATRA: Hast thou the pretty worm of Nilus there,

That kills and pains not?

GAVIN/CLOWN: Madam, I have him, but 'tain't go be me who go

Ask you handle him, because one nip from this

Small fellow and Basil is your husband; this little

Person will make the marriage, in poison and in

Person, but the brides who go to that bed don't

Ever get up. (Walcott, Branch, 1986, pp. 262-263)

Bakhtin, in The Dialogic Imagination, makes an important observation on parodic texts: "Each separate element in it [parodic language] — parodic dialogue, scenes from everyday life, bucolic humour, etc.-is presented as if it were a fragment of some kind of unified whole" (1981, pp. 59-60). Walcott's text revels with many of these whole subtexts. Above, we have seen Gavin as the clown speaking entirely, although in the context of a Shakespearean play, in colloquial Trinidadian dialect. Marilyn and Sheila before her perform whole authentic segments of the Shakespearean text. Harvey, in his directorial parodies, gives, in the previously quoted piece of dialogue, a whole microcosmic version of the plantation slave driver and then shifts into a parody of the cynical producer. Theatre, even more than the novel, depends on, and abounds in, such "speech-genres" (Bakhtin Speech Genres). Dramatic parody would become indecipherable if these speech units were reduced into much smaller proportions, however; the audience would fail to follow them. "In poetry, linguistic parody can succeed more easily word after word, not just passage after passage, since the reading audience has the written text to study" (Hamner, 1997, p. 392). Walcott complicates his intertextual parody in A Branch of the Blue Nile probably as densely as is possible without utterly losing his aural audience.

The play continues, from beginning to end, to display "a plethora of interanimated texts." Once the Trinidadian troupe, with Marilyn as Cleopatra, finally performs Shakespeare, the performance is marred by a ludicrous mistake of scenery when one of Chris's sets is pushed onto the stage: it is painted with banana trees instead of the proper Egyptian set. Later Gavin reads the local critic's notice of their performance, which rips Harvey, the director, for allowing such an error to occur but "which obsequiously lavishes the hyperbolic praise of a fawning critic on Marilyn's performance." Walcott here is "parodying the excessive-and all too typical-language of newspaper criticism" (Hamner, 1997, p. 392).

As the play moves towards conclusion, Walcott inserts several long, truthful, self-revealing speeches: Gavin's rehearsal of his previous humiliation as a black actor trying to make it in New York; Sheila's paroxysm of shame from allowing herself to have an affair with Chris, a married man (a scene which catapults her into religious conversion); and Chris's angry outburst at all the others for failing to understand the essential linguistic/political paradoxes which compromise all of them as post-colonials with a hybrid language and culture. Chris quits the troupe to open a restaurant in Barbados, which he names "A Branch of the Blue Nile." Later, when he returns to Trinidad, he discusses the title of his restaurant and reveals its symbolic allusion to Cleopatra's river and to his earlier angry statements about the frustrating paradox of black, post-colonial culture adopting, mimicking, and twisting white (instead of blue) cultural and linguistic forms.

The irony of Chris's position cuts many ways, however, because he has come back, like Antony to Octavia, to his white wife; yet he returns again to Trinidad, still pining with love for Sheila, to lure her away from the fundamentalist church. What is his tool to do so? None other than another play he has written specifically for Sheila in a central role. He confronts her with his script and recites her part for her in an attempt to seduce her back to the stage. She does visit their original theatre space, but for her it is, alas, too late: Chris has returned to Barbados; Marilyn has gone on to a career in New York; Harvey has departed to London, where he dies from a sudden disease, possibly AIDS. Sheila is left onstage with the ultimate parodic mimicry: the play by Chris which is an exact playback (from a tape recorder which he had let run during their earlier rehearsals), performed by a foolishly frolicking couple, Iris and Wilfred. "The play ends, in another characteristically Shakespearean form, with an appearance by a 'fool' character, Phil, who gives the play closure with his scatterbrained but deeply wise exhortation" to Sheila (Hamner, 1997, p. 393), as a talented but uncertain actress: "Continue. Do your work." The serious implications of Walcott's drama finally catch up with and triumph over the play's comic elements.

Walcott has said (at a conference in Florida) that North American society contains a multitude of cultural/linguistic hybrids but that its theatre is unfortunately lacking-if he were to use Bakhtin's terms-in "interanimated, heteroglotic hybrids." A Branch of the Blue Nile brilliantly begins to fill this gap. It wonderfully fulfills many of Bakhtin's concepts of "parodic heteroglossia," a multitude of linguistic shifts that "demonstrate a seriocomic imagination, that mix low and high forms, and that strive to renew the established literary tongue by drawing on the fundamental elements of folk language" (Bakhtin, The Dialogic Imagination, 1981, p. 49).

Although Mikhail Bakhtin in his The Dialogic Imagination (1981) sees the mixing of linguistic forms, the markers of languages and styles as an important aspect of what he calls "intentional hybridity," it is the collision between the different points of view on the world that may be embedded in these forms which for Bakhtin is the most prominent feature of intentional hybridity (1981, p. 360). 


\section{B. The Vernacular in its Traditional Place}

We meet the whole cast when they are rehearsing Shakespeare's Antony and Cleopatra. Gavin, playing Cleopatra, sticks to Shakespeare's lines, but Chris as Enobarbus changes Shakespeare's lines, speaking them in his own vernacular: GAVIN: "Saw you my lord?"

CHRIS: Your lord? No. He gone out.

[Laughter. Gavin controls his laughter, resumes]

GAVIN: "Was he not here?"

[Sheila opens her eyes, leaps up]

CHRIS: You deaf? He was disposed to mirth,

But on the sudden a Roman thought hath struck him. Pow! (Walcott, Three Plays, 1986, p. 214)

At this point in the play, Chris's insistence on using his own vernacular to speak Shakespeare's lines may seem nothing more than "creolising Shakespeare as part of their rehearsal process for two contrasting plays " (Stone, 1994, p. 136), but it also foreshadows Chris's position as to the use of language, and its meaning for the definition of his cultural self.

Sheila gives a staggering performance as Cleopatra. No doubt she is capable of brilliantly presenting Shakespeare's classic lines, which shows that the plays main concern is not the question of whether or not the West Indian actor is capable of classical form, rather, the West Indian audience's perception of and reaction to such a language will be at stake.

Any West Indian actor who wants to do professional theatre has to face a frustrating social reality or even his talent deepens his frustration. No matter how good Sheila's Cleopatra performance was, she would still have to do other work to make a living. And as she is black she knows that she cannot even go abroad to change her situation:

SHEILA: "I'm black. I'm West Indian. Who needs a broke, black, West Indian actress over thirty?" (Walcott, Branch, 1986, p. 238)

Chris and Sheila not only discuss the stage; the truth of their own relationship is also at stake. Just as Antony in Shakespeare's play returns to Octavia, Chris does not want to deepen his relationship with Sheila. He tells her that he has disclosed to his wife the truth about his affair with Sheila:

CHRIS: She has the truth and it is killing her.

SHEILA: And you can't bear to see her die. (Walcott, Branch, 1986, p. 234)

Walcott distinguishes between the truth of Sheila's calling and yet another truth, that of her inner self. Thus Sheila objects to Chris's mixing up of Sheila the actress, playing a role and Sheila the person living her life. She distances herself from her complete identification with the role of Cleopatra, but on another level, as Chris is asking her to go on a drive and have sex with her in a cheap motel; it literally means that he may dream about having sex with Cleopatra, the queen but not with her.

Through Sheila, as Sinnewe argues, Walcott reminds us of another image of the gift, "an image that neither distinguishes between classical/standard and vernacular/creole or European/non-European, but it is in itself a hybrid, namely the branch in Sheila's hand, the branch of the blue Nile." With it Walcott links the European and African roots of the Caribbean, "for the river is neither white nor black, but blue, it springs from the heartland of Africa, it flows to Egypt." The relation between European, specifically English, American and African culture, all of which influence the formation of the hybrid West Indian culture, "is not marked by hierarchy, but neither is it an uncomplicated mélange" (2001, p. 96).

In A Branch of the Blue Nile Walcott makes the writing of plays, the language they are written in, and an explicit topic. Chris has written a back-yard comedy, a play dealing with the life of ordinary people in the Caribbean. For Walcott, as for his character Chris, there is a choice to be made as to where one located the language of a character within the Creole continuum. We have seen how, for historical reasons, those language varieties that are closest to Standard English have a higher social prestige than those closer to the vernacular.

In her doctoral thesis "Creole Features in the Works of Three West Indian Writers-V. Reid, R. Mais and Derek Walcott: A Functional Approach", Saday Niang states that, in certain contexts, "tenors of power and formality select Standard English as their medium", because it is the language of "affirmation of social status", which has been gained through wealth, education and political achievement, "whereas Creole, as a low status idiom, is the language of deeply felt emotions or, as it also a despised medium, is considered vulgar and the medium for vulgarities" (1986, pp. 246-7).

Chris thinks that language somehow embodies culture, which is an essentialist view of language. However, to say that the language of a European classic has no place on his stage, because that is not the way he speaks off-stage, means suddenly to change position and to claim that only the vernacular is capable of embodying West Indian culture. For Chris a place, including its language, is a "defining element for cultural practices and for individual identity" (Sinnewe, 2001, p. 98), indeed, he has a point when he addresses Gavin, ironically using the latter's own Americanised jargon to tell him that he has been Americanised and because he has lost his roots, he has lost his identity:

CHRIS: You don't know what you are, Gavin. You don't know who to be ... Well this thing here [Chris's play] would have restored you to your origins, your roots, your language, your childhood, because you ass, that's where every artist starts from. (Walcott, Branch, 1986, pp. 249-50) 
Chris is right in pointing out that a place and its language are defining elements for one's identity. Surely, an artist may have his indigenous culture at the base of his art, but this should never lead him to shut himself off from other cultural influences, places and languages, which is precisely Gavin's point: "I'm no lasted writer, but you, you're the writer. How can you take any pride, any pleasure, in keeping your head empty?" (Walcott, Branch, 1986, p. 249) In terms of economics, one's artistic sensitivity or one's talent easily adapts to opportunities that may lay beneath one's own "superior" standards (Sinnewe, 2001, p. 98). The economic realities of the West Indies, as it has been stressed out by Chris's analysis of the economic situation, "mean a structural impossibility that does not allow for art in the West Indies to be more than an amateur pastime" (Sinnewe, 2001, p. 99).

Walcott, in A Branch of the Blue Nile, on the one hand, does not morally condemn Marylin's decision to try to get work abroad. However, on the other hand, he appreciates Sheila's decision not only to go back to Trinidad theatre, but to remain there as the only member of the former theatre group. "The courage that Sheila's decision requires, a courage that Walcott thinks any artist in the Caribbean must have", is underlined by a possible consequence of her decision to stay, most visible in Phil, "having been once a successful musician, enjoying a big local hit in 1963, is now a derelict" (Sinnewe, 2001, p. 108).

Walcott introduces the character Phil in the very first scene of his play. Phil's "You wasting your time, you wasting your time! ..." does not yet have the quality of a Cassandra call, it seems to be only the ramblings of a drunkard. However, in the course of the play Phil becomes the topic of conversation, and when Chris defends his insistence on local dialect as the only proper language for his plays, it is Phil who is given as an example:

CHRIS: You know who I write for, Mr. Come-Back Englishman? I write for that madman screaming in the street. His language.

Not somebody else's, not how you think madman should talk, as if insanity was literature. Phil is my Lear, my Mad Tom out in the rain, drenched in the savannah, in real life! (Walcott, Branch, 1986, p. 247)

But here Phil is not given a voice; he is only "the object of a discussion about the value that should be attached to the use of the vernacular on stage" (Sinnewe, 2001, p. 108).

In the first act, it seemed Walcott was still working with the "dichotomy of dialect versus proper speech"; as we see with A Branch of the Blue Nile, Walcott's position as to the "improperness of dialect will become modified." The link which Marylin establishes between Sheila's gift and the latter's capability of delivering the Bard's lines in "proper" English is obvious. "For Sheila her gift is God-given grace, and it was given to her through Shakespeare. In her religious fervour she even equates Shakespeare with God, holding the belief that this gift can be passed on" (Sinnewe, 2001, pp. 99-100). However, she thinks that divine intervention does not elevate her above worldly categories such as race and place when she says to Marylin, "You lighter-skinned than me, girl. You could work abroad" (Walcott, Branch, 1986, p. 258). Thus, however great Sheila's gift is, "from whatever divine origin it may stem, it is still a question of race, not grace" (Sinnewe, 2001, p. 100).

No matter how well Sheila may speak Shakespeare's lines and how close she may come to the European and American standard in terms of language, she will never meet the standard, regarding the amount of melanin in her skin. Harvey, being white, is on top in this racial hierarchy and although he initially denies the importance of Sheila's race for her career, "he has to concede that even the lighter skinned Marylin will not stand a chance in the world of European theatre" (Sinnewe, 2001, p. 104).

\section{Creolising Shakespeare-Validity of Hybridity}

The second act of Walcott's A Branch of the Blue Nile opens with a performance of Cleopatra's farewell scene from Shakespeare's Antony and Cleopatra. As Sheila has left, following what she thinks to be a calling from God, Marylin plays Cleopatra. Harvey has rewritten the Clown's/ Gavin's lines in indigenous dialect. Through Harvey's voice one can hear Walcott's comments on the West Indian actor and the language of Shakespeare:

Some of the finest Shakespeare I have ever heard was spoken by West Indian actors. The sound of Shakespeare is certainly not the sound we now hear in Shakespeare, that androgynous BBC-type, high-tone thing. It's a coarse thing-a great range between a wonderful vulgarity and a great refinement, and we have that here. We have that vulgarity and we also have that refinement in terms of diction. (Baer, 1996, p. 110)

Thus in Bakhtinian terms Harvey has not done anything new in that he mixes standard with non-standard, Shakespearean language with local dialect. "On the contrary, he claims that what seems to be homogenous, even the language of Shakespeare, always already has a hybrid character, as there lies in it an encounter between two linguistic consciousnesses, separated from one another by social differentiations." Harvey is not mixing different languages for "any parodic effect", but even if Harvey's intention was to parody, this would be an acceptable, even-if one follows Bakhtin's definition of unintentional hybridity - "ultimately natural stage in the development of any artistic form, which through its use has become too heavily stylised" (Sinnewe, 2001, pp. 100-101).

Therefore, "what the critic considers 'sacred', the pureness of homogenous character of Shakespeare's language is nothing less than a historical delusion." What threatens a civilisation or culture is not some form of hybridity, "but rather the closing off or preservation of artistic forms from other, foreign influences"; because it makes these artistic forms inert, incapable of interacting with the surrounding cultural environment. Thus, Harvey's explanation for creolising Antony and Cleopatra "not only denies any a priori cultural homogeneity", but furthermore, through the act of staging his creolised Antony and Cleopatra, he shows that even if a cultural form, an artistic expression, was once 
shaped through its place of origin, "it is legitimate to transport it to another culture" and let it be influenced by this culture (in this case through its language) as it is the only way that it will stay alive and have meaning (Sinnewe, 2001, p. 101).

On the one hand, Harvey raises the standard of his theatre company because he shows his actors that they with their art can go beyond the local standard which also means that they can enact plays that are not indigenous to their local culture. It seems that Harvey's attitude is "thoroughly cosmopolitan, excluding any traces of an overt or hidden racism." On the other hand, however, one can see that Harvey "consciously uses what can also be considered a racial stereotype"; because he "furiously compares the local critic with an ape" (Sinnewe, 2001, p. 101). "Lecherousness", according to Dirk Sinnewe, "is yet another racial stereotype" and if one reads this in the context of Harvey's assumption that "the local critic lacks erudition" (2001, p. 102), and that if he has read the play at all he did it "moving his lips and all. He's got two thumbs on his feet ... he turns the pages with them" (Walcott, Branch, 1986, p. 268). Although Harvey apes the critic's affectation for thinking in stereotypes, his play, nevertheless, "makes the point that no form of cultural expression is bound to have validity only at its place of origin" (Sinnewe, 2001, p. 102).

Walcott's experiences with the Trinidad Theatre Workshop, according to Sinnewe, "are not exclusively reflected in one of the characters, but in all of them." It seems "an obvious choice to identify the director Harvey St. Just or the writer/director Chris with Walcott himself." His experiences are thus dispersed onto the positions held by a variety of characters, yet there are a few arguments which would allow "for Phil to be seen as a mouthpiece for some of Walcott's most personal convictions regarding the world of theatre." He may seem a madman or a fool, but as in Shakespearean theatre, "the madman/ fool often has a good deal more wisdom than the director/ king" (Sinnewe, 2001, p. 109).

Thus Phil's function is twofold: on the one hand he is allowed to express and comments on the conflicts that exist between differing approaches towards the theatre (amateurism versus professionalism, the classical versus the indigenous and the use of Standard English versus the vernacular). But on the other hand, in terms of structure, Phil, by serving the same function as "the chorus of a Greek play or a Shakespearean fool", gives Walcott's A Branch of the Blue Nile a very classical form indeed (Sinnewe, 2001, pp. 108-109). Phil accuses that the government does not support the arts with even stronger words, an accusation which Walcott has also repeatedly voiced. But it is not only the government which is at the receiving end of Phil's criticism; it is also the artists themselves, "the frequent lack of professionalism" on his actors part under which Walcott suffered repeatedly (Sinnewe, 2001, p. 110).

A theme of A Branch of the Blue Nile is the use and misuse of talent, especially in the arts. Sheila, both hurt by Christopher and fearing her ambitions, retreats to a fundamentalist religious group. The title of the play comes from her explanation of why she gave up playing Cleopatra and quit the theatre for the church: " 'cause the Caroni isn't a branch of the river Nile, / and Trinidad isn't Egypt, except at Carnival, / so the world sniggers when I speak her lines" (Walcott, Branch, 1986, P.285). But discovering that "her talent as an actress is wasted as a gospel singer, Sheila returns to the struggling theatre company" (Hamner, 1997, p. 367).

A Branch of the Blue Nile ends with the rehearsal of the next generation of actors who continue the work of those who have left and Sheila will be there to help them. Therefore, one could argue that "Walcott sees hope for a continuation of the artistic efforts in the Caribbean" (Sinnewe, 2001, p. 111), and Phil's closing speech seems to underline this positive outlook:

Phil: Show me your palm. Good lines. Good branches. [He bows] Press on. It touch me once, that light. It fill me full ... I was his vessel. And it don't matter where it is: here, New York, London. No, miss. Believe me, Phil knows show business. [Turns. Sheila sits on a platform] Get up. Do what you have to do. For all our sakes, I beg you. Please. Continue. Do your work. Lift up your hand, girl. (Walcott, Branch, 1986, p. 312)

It is Phil's vernacular that is allowed to carry these tenets, "adding to them the quality of a deeply felt emotional truth." When Sheila finally continues rehearsing, she draws her hope not from a success, but a failure. The final sound we hear in A Branch of the Blue Nile is Sheila's breathing, “...driven to the pitch of exhaustion" (Walcott, Branch, 1986, p. 312). "Thus, although Sheila continues her works, her breathing might foreshadow not only the tremendous amount of misery that she will have to go through in order to follow her calling, but also her possible defeat" (Sinnewe, 2001, p. 111).

With A Branch of the Blue Nile Walcott makes "a strong statement for the validity of a hybrid West Indian culture." He portrays the relation between European, specifically English, as well as American and African culture as one that should not be marked by a hierarchy, which places the culture, specifically the languages of the cultural centres, America and Europe at the top and African culture or the mix of all these cultures (and their languages) at the bottom. "Walcott's strategy here is to show that the so-called standards, Shakespeare's 'classical' plays and their language are already of a hybrid character, and any attempt to characterise them as homogenous entities and preserve them as such may ultimately result in their inertness" (Sinnewe, 2001, p. 111).

\section{Vernacular: A Necessity to Define Identity}

In A Branch of the Blue Nile, Walcott uses "the properties of an intentional artistic hybrid" in his quest for the shape of West Indian identities. Walcott links the question of language with the question of a definition of West Indian identities. This link is discussed on the level of content as well as on the level of style. In A Branch of the Blue Nile, the role which the vernacular played and to some extent still plays on the West Indian stage is made an explicit topic. Walcott shows us that the vernacular on and off stage is "capable of transporting more than petty witticisms or sexual 
insinuations." We learn that the actors (in Marylin this becomes most visible) think of their own capabilities for being good actors as directly linked to their command of Standard English (Sinnewe, 2001, p. 113).

Furthermore, Walcott shows us that these Trinidadian actors see their vernacular as misplaced when rehearsing a Shakespeare play. Walcott reminds us that already in Shakespeare we find "the mixing as well as the dialogical opposition between different languages (heteroglossia). He informs us of the fact that Shakespeare's language never was as homogenous or as pure as it is today deemed to be." In addition to this Walcott shows how language use can indeed "not only define identities, but also entrap us in certain prefabricated images of ourselves." By the end of the play, however, the role of the vernacular as a means of cultural expression on stage has changed, transporting more than petty witticisms on stage. Off stage, it is Phil whose vernacular carries "wisdom containing art and the state of the theatre worthy of the wise fool's insights in any of Shakespeare's dramas" (Sinnewe, 2001, pp. 116-117).

Walcott shows us that there is no such thing as purity, either in language or culture. What Bakhtin terms as "unintentional hybridity" is made concrete by Walcott's dramatic character Harvey in A Branch of the Blue Nile who "claims that even Shakespeare's language was a hybrid" (Walcott, Pantomime, 1980, p. 150). Any identity, any language use that may shape (cultural) identities is already, to greater or lesser extent, of a hybrid nature. Seen in this light, Walcott's plays answer the question of whether "classic theatre has a place in a Creole environment." In A Branch of the Blue Nile, Walcott is "at pains to show that cultural practices are valid not [merely] at their place of origin, for the idea of such absolute origins exists only in theory, and does not correspond to observed reality" (Sinnewe, 2001, p. 118).

In A Branch of the Blue Nile, Walcott portrays the vernacular as being "capable of voicing the ideas necessary to define one's identity." He also shows us in this play "the value that should be attached to the use of the vernacular on the West Indian stage, its importance for a definition of the West Indian cultural identity." The vernacular he portrays is thereby never a one-to-one transcription of the English or French Creole as it is actually spoken on the various Islands. As we have seen, it necessarily needs to be an adaptation of translation, as even from one island to the next; speakers of Creole will not immediately understand each other (Sinnewe, 2001, pp. 122-123). Meanwhile, it takes a closer look at how Walcott comments on the binaries, classical and vernacular (creole), and how far Walcott uses the properties of an intentional artistic hybrid to comment on the hybrid cultural identity of the Caribbean and, ultimately, of all societies.

With A Branch of the Blue Nile Walcott makes a strong statement for the "validity of a hybrid West Indian culture." He portrays the relation between European, specifically English, as well as American and African culture as one that should not be marked by a hierarchy. "Walcott's strategy here is to show that the so-called standards, Shakespeare's 'classical' plays and their language are already of a hybrid character, and any attempt to characterise them as homogenous entities and preserve them as such may ultimately result in their inertness” (Sinnewe, 2001, p. 111).

\section{CONCLUSION}

The authors of this article have argued that in Walcott's play A Branch of the Blue Nile Walcott uses the properties of an intentional artistic hybrid in his quest for the shape of West Indian identities. If Walcott, searching for a definition of West Indian (cultural) identities, ultimately shows the constructedness of a hierarchy between, for example, the Creole and European culture and thus deconstructs such a false hierarchy, then the interesting point is to look at how precisely he does this. Here the use of Bakhtinian notions with regard to language helps to avoid ideological simplifications. For Bakhtin, hybridity is a phenomenon of language formation, but also of the concrete and social act of language use, and his definitions allow one to look coevally at matters of style and content. It is from this basis, looking firstly at how Walcott comments on the issue of language, and how he himself employs the vernacular in his play, that the researchers finally venture to assess Walcutt's notion of language use, that is, specifically the use of non-Standard language and then its relation to the formation of West Indian (cultural) identities. After her reading of A Branch of the Blue Nile, the authors of this paper propose the following:

Firstly, Walcott links the question of language with the question of a definition of West Indian identities. This link is, as we have seen, discussed on the level of content, that is, Walcott explicitly comments on the use of language, as well as on the level of style. He portrays this link as not one of essence (you are what you speak) but of use (how you use languages may define you).

Secondly, in A Branch of the Blue Nile, the role which the vernacular played and to some extent still plays on the West Indian sage has made an explicit topic. Walcott shows us that the vernacular on and off stage is capable of transporting more than petty witticisms or sexual insinuations. We learn that the actors (in Marilyn this becomes most visible) think of their own capabilities for being good actors as directly linked to their command of Standard English. Furthermore, Walcott shows us that these Trinidadian actors see their vernacular as misplaced when rehearsing a Shakespeare play. The rightful place of the vernacular is ascribed to Chris's back yard comedies, but not to Shakespeare's plays. Nevertheless, Walcott reminds us (through Harvey) that already in Shakespeare we find the mixing as well as the dialogical opposition between different languages (heteroglossia). What is more, the playwright informs us of the fact that Shakespeare's language never was as homogeneous or as pure as it is today deemed to be. In addition to this Walcott shows how language use can indeed not only define identities, but also entrap us in certain prefabricated images of ourselves. This is most visible in Gavin's use of American English, itself yet another non-West Indian Standard, which, as we have seen, Walcott also portrays as not speaking to the situation of Afro-Americans in the West Indies. By the end of the play, however, the role of the vernacular as a means of cultural expression on stage 
has changed. The dramatic character Chris finally allows the vernacular to transport more than petty witticisms on stage. Off stage it is Phil whose vernacular carries wisdom concerning art and the state of the theatre (in the West Indies) which is worthy of the wise fool's insights in any of Shakespeare's dramas.

Thus one can say that in A Branch of the Blue Nile, Walcott firstly makes the reader or the audience aware of the disregard one still has for the vernacular (especially for the English and French based Creole) when compared to Standard English. He also makes us aware of the ideology from which such a view historically stems. Later, Walcott re-invests value into the use of the vernacular, and he shows us that there is nothing which one cannot express with vernacular, especially the tenets of one's identity. He shows us that what we consider as pure or homogeneous is nothing less than a historical delusion. Even what we today may consider homogeneous, a language or a culture, is always already to a greater or lesser extent a mixture of elements.

\section{REFERENCES}

[1] Baer, William. (1996). Conversations with Derek Walcott. Literary Conversations series (eds.). Jackson: University Press of Mississippi.

[2] Bakhtin, Mikhail M. (1981). The Dialogic Imagination: Four Essays by M.M. Bakhtin (eds.). Trans. Michael Holquist. Caryl Emerson, and Michael Holquist. Austin and London: University of Texas Press.

[3] Bakhtin, Mikhail M. (1986). Speech Genre and Other Late Essays (ed.). Trans., Vern W. McGee, Caryl Emerson and Michael Holquist. Austin: University of Texas Press, 60-102.

[4] Hamner, Robert D. (1997). Critical Perspectives on Derek Walcott (eds.). Colorado Springs: A Three Continents Books (Lynne Rienner Publishers), Inc.

[5] King, Bruce. (1987). The Collected Poems and Three Plays of Derek Walcott, In Critical Perspectives on Derek Walcott, edited by Robert D. Hamner, 361-368. Colorado Springs: A Three Continents Book (Lynne Rienner Publishers), Inc., 1997.

[6] King, Bruce. (1981). Derek Walcott. Boston: Twayne.

[7] King, Bruce. (1997). Derek Walcott \& West Indian Drama: Not Only a Playwright But a Company, The Trinidad Theatre Workshop 1959-1993. Oxford: Claredendon Press.

[8] Niang, Saday. (1986). Creole Features in the Works of Three West Indian Writers-V. Reid, R. Mais and Derek Walcott: A Functional Approach, diss. New York: Ontario, 246-7.

[9] Shakespeare, William. (1969). Antony and Cleopatra, in William Shakespeare: The Complete Works. Baltimore: Penguin.

[10] Sinnewe, Dirk. (2001). Divided to the Vein? Derek Walcott's Drama and the Formation of Cultural Identities. Würzburg: Königshausen \& Neumann.

[11] Stone, Judy J. (1994). Theatre: Studies in West Indian Literature. London and Basingstoke: Macmillan.

[12] Thieme, John. (1999). Derek Walcott. Manchester: Manchester University Press.

[13] Walcott, Derek. (1986). A Branch of the Blue Nile, in his Three Plays. New York: Farrar, Straus and Giroux.

[14] Walcott, Derek. (1980). Remembrance and Pantomime: Two Plays. New York: Farrar, Straus and Giroux.

[15] Walcott, Derek. (1986). Three Plays: The Last Carnival, Beef, No Chicken, A Branch of the Blue Nile. New York: Farrar, Straus and Giroux.

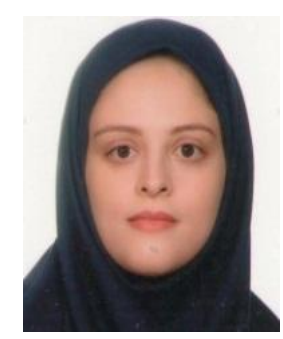

Zohreh Ramin (The Corresponding Author) is the assistant professor of English language and literature in Department of English in University of Tehran, Iran. She received her bachelor's degree in English language and literature from University of Isfahan in 1999, and both her master's degree and Ph.D. degree in the same major from University of Tehran in 2003 and 2011.

She is currently instructing in Tehran University. She has written a lot of articles some of which are listed here:

Shakespeare's Richard III and Macbeth: A Foucauldian Reading. (2013). Kata 15, No. 2, 20-35.

Revision of the American Frontier in Doctorow's Welcome to Hard Times. (2014). International Letters of Social and Humanistic Sciences 17, No. 2, 150-160.

E. L. Doctorow's World's Fair: The Political Power of Ventriloquism. (2017). The Explicator 75, No. 1, 25-27.

Dr. Ramin, as an academician, is an active participant in various national and international seminars and symposiums. She has been supervising and advising a lot of theses and dissertations, along with holding and monitoring a lot of academic projects in Tehran University since she has graduated there.

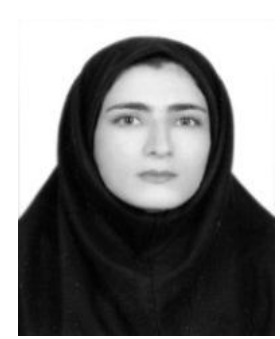

Monireh Arvin was born in Province Ahar, located in Tabriz, Iran. She received her bachelor's degree in English language and literature from Karaj Islamic Azad University; in 2005, and her master's degree in the same major from the same university in 2008. She is currently a Ph. D. Student of English literature in the department of English, in Alborz Campus, University of Tehran, Iran. Her research interests included literary criticism and post-modern studies.

She has worked as an English instructor at various universities including Parand Islamic Azad University, Karaj Islamic Azad University, etc. She is currently teaching English language and literature in Karaj Islamic Azad University and some language institutes. Meanwhile, she has majored in French language and she is teaching it in some language institutes. She has participated in numerous international and national conferences, and has written two books and a lot of articles some of which are listed here: 
A Symbolic Deconstructed Colonialism in A Passage to India by E. M. Forster. (2015). Environment Conservation Journal, Uttarakhand, India. Vol. 16, No. Special Edition (SE), 223-229.

Reality versus Fantasy in William Dean Howells' Editha and Luigi Pirandello's War. (2015). Jurnal UMP Social Sciences and Technology Management, Malaysia. Vol. 3, No. 1, 803-808.

Socialism and the Possibility of Utopia in The Wesker Trilogy. (2016). Mediterranean Social Science Journal, Italy, Rome, Vol. 7 , No. 3, S1, 296-302.

Dr. Arvin has obtained The Best Paper Reward in ICELL (November 16-17, 2016: 18th International Conference on English Literature and Linguistics.) Dubai, UAE for her paper "Frank Norris' McTeague: An Entropic Melodrama. 